\title{
Acontecências: um mosaico da condição humana
}

\author{
Paulo Evaldo Fensterseifer \\ Universidade Regional do Noroeste do Estado do Rio Grande do Sul - UNIJUí \\ Email: fenster@unijui.edu.br \\ Lisiane Goettems \\ Instituto Federal Farroupilha- Campus Panambi/RS \\ Email: goettems@iffarroupilha.edu.br \\ Eduarda Virgínia Burckardt \\ Centro de Educação Básica Francisco de Assis - EFA ljuí/RS \\ Email: eduarda_lang@hotmail.com \\ Carolina Gehrke \\ Universidade Regional do Noroeste do Estado do Rio Grande do Sul (UNIJUÍ) ljuí/RS \\ Email: kk.roglin@hotmail.com
}

Resumo

O artigo recupera a trajetória de criação e desenvolvimento do Projeto Mosaico, ofertado no Centro de Educação Básica Francisco de Assis- EFA, ljuí/RS, sob a coordenação geral de profissionais da Educação Física. Destaca a terceira oferta do Projeto Mosaico (2014), cujo tema gerador- a condição humana- trabalhou a perspectiva da condição humana e seus desdobramentos, experimentados na dimensão de leituras, debates, colocados em experiências de lutas, ginástica, dança, canto, poesia, criação de movimentos, adereços, na exploração de cores, cenários, cenas e deram origem ao Mosaico- Acontecências. Nessa edição, houve a participação de diferentes segmentos escolares (discentes, docentes, familiares, comunidade externa), formando interação entre diferentes idades (entre 5 anos a 70 anos de idade).

Palavras-chave

Condição humana.Escola.Linguagens. Expressão Corporal.
Abstract

The article recovers the creation and development of the Mosaic Project, offered at the Francisco de Assis-EFA Basic Education Center, ljuí / RS, under the general coordination of Physical Education professionals. It emphasizes the third offer of the Mosaic Project (2014), whose generative theme - the human condition - worked out the perspective of the human condition and its unfolding, experienced in the dimension of readings, debates, experiences in struggles, gymnastics, dance, singing, poetry, creation of movements, props, in the exploration of colors, scenes, scenes and gave origin to the Mosaic- Events. In this edition, there was the participation of different school segments (students, teachers, family members, external community), promoting the interaction among different ages (between 5 years to 70 years of age).

Keywords

Condition. School. Languages.Body Expression. 


\section{Mosaico: primeiros passos}

O Centro de Educação Básica Francisco de Assis (EFA), ao longo de sua história de quase cinquenta anos, tem mantido estreita ligação de suas propostas à dimensão artística- teatro, expressão corporal, dança, música, artes visuais, lutas, ginástica geral e artística. Essas ênfases desenvolvidas no âmbito da escola valorizam a linguagem corporal e expressiva, as quais se fortalecem ano a ano através da organização curricular que contempla e valoriza este conjunto de estudos, bem como, através da oferta de projetos oferecidos em contra turno.

Através desta perspectiva os alunos têm a possibilidade de serem conhecedores de obras de artes, das produções dos artistas brasileiros e de outros países. Também, desenvolvem a sensibilidade para com a arte, tornando-se críticos, apreciadores, sendo incentivados também, a experimentarem suas próprias autorias através de experiências artísticas. A proposta escolar permite ainda o acesso ao estudo instrumental, vocal, teatral o que, no conjunto, provoca a formação de sujeitos com desenvoltura, arguição, curiosidade.

A arte circula na escola: corredores, sala de aula, projetos, pesquisas, reuniões de pais, eventos. E, foi esta diversidade de atuações que despertou a ideia de propor um projeto anual que pudesse aproximar as diferentes linguagens corporais (dança, música em vocal/ instrumental, lutas, teatro, ginástica) já ofertadas à comunidade escolar. Como potencialidade do projeto se desenhou a intenção de reunir as diferentes expressões em diálogo entre si e, também, reunir as diferentes faixas etárias, ou seja, ter alguns momentos e local que todas as ofertas e envolvidos pudessem se reunir viven- ciando e trocando experiências.

Nas ofertas anteriores que a EFA vinha desencadeando, em relação as linguagens corporais, os grupos se formavam pelo interesse na modalidade, em grupos com faixa etária aproximada (crianças, jovens e adultos). Não se visava terminar com esta ideia e colocar outra em seu lugar. Tratava-se, pois, de encontrar mais um modo de vivenciar as ofertas, desta vez em um coletivo ampliado que pudesse valorizar cada experiência e habilidade dos integrantes.

A partir de então, foram realizados convites, reuniões formais, registro de ideias, criação de roteiros, escolhas de música, trocas de materiais e textos. As modalidades específicas continuaram sendo ofertadas na escola, porém em determinados momentos das aulas de cada modalidade, se deixava um tempo para focar em temáticas comuns entre todos os grupos. Para tal, se potencializava espaços para conversas, leituras, trocas de materiais, questionamentos, vivências e posteriormente encontros coletivos fazendo dos muitos grupos uma única coletividade.

As temáticas desencadeadas podiam ser propostas pelo professor e também pelos alunos. A pesquisa era desenvolvida de modo a encontrar um tema norteador para assim, poder tecer a rede de significados que, poderiam (ou não) se transformar em vivências para o momento presente e/ou cenas futuras que viriam a compor um espetáculo. Essas partes de cenas capacitavam a formação de um texto maior em constante discussão e compreensão.

As ressignificações de ideias, de movimentos, de posições e posturas corporais, as alternâncias de músicas e a criação de cenários e fantasias, foram produtoras de momentos 
de entusiasmo e autorias. No conjunto dos participantes, de faixa etária entre três e cinquenta e cinco anos de idade, decidiu-se pela socialização das ideias em forma de apresentação artística. Assim, durante o ano o grupo foi acertando o compasso entre o mundo das ideias e das ações, para enfim mostrar para toda a comunidade escolar suas elaborações.

O projeto iniciado no ano de 2009 recebeu contribuições, inclusive, na projeção do nome: "Projeto Mosaico". Justifica-se a escolha pelo significado original da palavra mosaico que consisteem muitas partes que, em aproximação umas das outras, produzem um determinado efeito visual. As muitas partes que podem formar desenhos, imagens, mensagens, comunicações.

Até então, houve três edições do Projeto Mosaico, desenvolvidos no ambiente da EFA. Em todas as ofertas ocorreu a participação efetiva de alunos, professores, funcionários, pais, avós, amigos o que reitera que apesar da larga escala de diferença de faixa etária todos os participantes, a seu modo e possibilidade, obtinham espaços para compreender, opinar, fazer, decidir, desistir e aprender sobre o tema em debate e ação.

Na edição I o tema gerador envolvia refletir sobre o tempo e depois de longas tentativas denominou-se "Vida e tempo no tempo da vida". O tema requereu explorações diversas: poesias, trava línguas, músicas (ao vivo vocal e instrumental), aproximadas as linguagens corporais da dança, expressão corporal, luta e ginásticas. O lançamento da ideia ocorreu em duas sessões: uma para professores e familiares na comemoração do dia do professor e outra noite para comunidade escolar e amigos.

$\mathrm{Na}$ edição II denominada "Depende do ângulo que você vê" o tema focou refletir sobre a influência da televisão e da globalização na vida diária das famílias, os modos de administração que cada ser humano organiza para com as escolhas que elege importante. Através da comunicação corporal e verbal, se provocou pensar que aquilo que é de suma importância para alguns, pode representar pouco interesse para outros, pois, depende do ângulo que vemos e administramos as cenas da vida, podemos ser agitados, felizes, ficar tristes, aprender. Enfim, podemos receber ou suspeitar das influências que o consumo insiste em nos ofertar.

Já na III edição, o tema explorado foi a Condição Humana, recebeu o nome de "Acontecências", esforço em dizer do humano, desse ser inacabado que tem como traço distintivo problematizar sua própria natureza (ou a ausência de uma natureza). Como escreve João Guimarães Rosa (1986, p. 21): “(...) o mais importante e bonito, do mundo, é isto: que as pessoas não estão sempre iguais, ainda não foram terminadas - mas que elas vão sempre mudando". Pensamos então em trazer para o palco essa dificuldade de nos dizer conceitualmente, recorrendo as diferentes linguagens que caracterizam a proposta do Mosaico ${ }^{1}$.

\section{Onde tudo começou²}

Em meio a muitos debates sobre a Educação Física e seus saberes, fomos diversas vezes interrogados com questões que pareciam óbvias-banais, fazendo com que nossas certezas se tornassem incertezas. E em meio a este turbilhão de ideias, refletir tornou-se indispensável.

1 Falávamos de algo como "dançar a condição humana".

2 A intenção neste momento é compartilhar como iniciou a organização da III edição do Mosaico. 
Nesse processo, fomos tendo algumas percepções, algumas óbvias, entre elas, a de que não nascemos prontos, mas que vamos aos poucos nos transformando em seres humanos, segundo Kant (1996), não nascemos humanos, nos tornamos humanos pela educação, e esta, acrescentamos, é sempre sujeita a determinantes histórico-culturais. Nesse momento, muita coisa muda de sentido, e passamos nos perceber, neste contexto de seres humanos sempre em construção.

Apresentados ao texto, Condição Humana e Educação (Fensterseifer, s/d) fomos impulsionados, pelo entendimento de humano sugerido,com que estabelecêssemos novas relações com nossa realidade, nos dando vontade de levar isto adiante, e disseminar esta ideia, entre as diferentes realidades de forma que isto fizesse sentido na vida de outras pessoas em diferentes contextos, assim como fez na nossa.

\section{Um passeio pelas ideias ${ }^{3}$}

"O homem é a única criatura que precisa ser educada" (Kant, 1996, p. 11). Essa ideia, primeira frase do livro de Kant sobre Pedagogia, já nos dá o que pensar, afinal: não nascemos humanos? Porque temos que ser educados?

Fica evidente que muitas das ideias contidas nesta reflexão podem ser tomadas por óbvias, algo que não chega a constituir-se em um problema se reconhecermos que o óbvio é aquilo sobre o qual paramos de pensar. Compreensão que se articula com a definição de filosofia de Merleau-Ponty, segundo o qual a

3 Vamos trazer aqui algumas das ideias do texto que serviu de inspiração para pensar o tema e que foi apresentado, com o recurso de imagens, aos potenciais participantes da "aventura" que nos lançávamos, crentes de que algo iria "acontecer". verdadeira filosofia é "reaprender a ver o mundo" (1994).

A primeira das obviedades é a aceitação do fato de que não nascemos humanos, mas, concordando com Kant, nos tornamos humanos pela educação. Assim, se nos animais ato e potência coincidem, no Homem isso não acontece. Nos primeiros a direção do desenvolvimento já está previamente traçada, enquanto no Homem a própria direção é uma construção humana, balizada pelos determinantes histórico-culturais.

Como "seres no mundo", somos historicidade, e nosso pertencimento ao mundo, precede qualquer tentativa de estabelecer uma "essência", o que faz com que aquilo que chamamos "natureza humana", seja um sentido instaurado por nós humanos. É este entendimento que torna compreensível que em alguns momentos da história já tenhamos nascido "naturalmente desiguais" (fenômeno que se repete nas comunidades de castas), e em outros, "naturalmente iguais" (como nas sociedades republicanas).

Fazendo uma analogia com as "melancias quadradas" dos japoneses, desenvolvidas no interior de caixas de vidro, podemos afirmar que os seres humanos desenvolvem-se no interior de "caixas de vidro" produzidas por diferentes modelos civilizatórios e culturais.

Seu modelo pode variar, mas sua existência, se concordarmos com a máxima freudiana, de que "sem coerção não há civilização", é imprescindível, uma vez que, diferentemente das melancias, não temos um modelo natural. Ser "humano" já é estar mergulhado/inserido na "caixa de vidro" da cultura.

Tomando cultura no sentido weberiano que propõe Geertz (1989), como teia de significados na qual nós nos inserimos tecendo-a, podemos afirmar que a educação, em sentido 
amplo, nos insere na cultura, potencializando-nos para "tecê-la". Pré-requisito para isto é tratar os conteúdos veiculados pelas diferentes instâncias educativas, como construções históricas, o que significa, passíveis de alterações pelos sujeitos que a produzirão.

Uma época que reabre a discussão a respeito da direção a ser seguida, é uma época de crise, pois em períodos "normais", basta remar, a direção do barco está determinada por uma tradição segura de seus propósitos e destinos.

Alguém hoje, salvo seitas fundamentalistas de caráter político ou religioso, demonstra inteira convicção do caminho a seguir? No plano religioso há muito as pessoas definem sua religião "a la carte"4.

No plano político, salvo os referidos fundamentalistas, as medidas políticas de esquerda e direita ficam difíceis de serem rotuladas numa época em que, usando expressão de Marx, "tudo que é sólido se desmancha no ar". O que vale para os signatários das sociedades planejadas, ou para os adeptos da livre iniciativa regulada pelo todo poderoso mercado.

Os profetas do Apocalipse arvoram-se em proclamar o "fim do mundo", os quais tiveram na virada do milênio seu momento mais propício, mas o século XXI parece não ter dado ouvido a estes profetas e segue a roda do tempo. Outros falam em "fim de um mundo", aquele identificado com o que convencionou-se chamar modernidade, e preconizam novos tempos pós-modernos, ou neomodernos.

$\mathrm{Na}$ busca de alternativas muitos voltam seus olhos e ações para o porto seguro do passado, os quais chamamos costumeiramente re-

4 Mais que isso, temos hoje, no plano religioso, mais que um cardápio, uma possibilidade de "compor seu próprio prato", algo como um "self-serv". acionários. Estes vivem como que em "caixas pretas", onde a única janela transparente está voltada para o passado. É neste passado supostamente ordenado e hierarquizado que residiria a saída possível da crise.

Já as saídas críticas, parecem ter perdido seu otimismo ingênuo de rupturas radicais com a tradição, desfazendo-se de bandeiras como as da "revolução", "novo tempo", "homem novo", e por aí afora. Informados hermeneuticamente, não ignoram o peso da tradição, nem a julgam maniqueísticamente como "fonte de todos os males", reconhecendo que o mundo é produção histórica situado na tradição, e é do seu interior que esboçamos um esforço crítico. Que será tanto mais crítico quanto mais tiver presente as condições históricas que forjam os critérios de sua crítica.

Invocando Marx, é preciso lembrar que o Homem faz sua história, mas não a faz sem considerar os limites que seu contexto histórico the impõe. Não se funda um novo tempo atirando nos relógios e ignorando, como sabia Raul Seixas, que nascemos "há dez mil anos atrás".

Somos apenas a "ponta do iceberg" chamado humanidade. Produtos, em parte, dos projetos instituídos que nos antecederam, e em parte da nossa capacidade instituinte. Se estes projetos estão "com seus prazos de validade vencidos", voltamos a afirmar, estamos em crise, situados "entre o não mais e o ainda não" (Arendt, 2002, p. 35-36).

Mas como, diferentemente de animais e vegetais, não vivemos sem projetos, ideais, sonhos, no máximo sobreviveremos sem eles, faz-se necessário forjar o "feno que nos põe a caminhar"5 e em função do qual educamos

5 Pensamos aqui na imagem do sujeito que, sentado sobre o lombo de um burro, segura uma vara na ponta da qual há um 
as novas gerações, mesmo sabendo que elas possam reprovar nosso "feno" e forjarão outras razões para suas vidas.

Como a vida não é uma corrida de orientação onde o mapa já está previamente traçado. Como nosso DNA não determina as condições histórico-culturais. Como, no dizer do poeta Fernando Pessoa, "navegar é preciso, viver não é preciso" (não tem norte magnético que nos oriente). Precisamos projetar o futuro, tomando o cuidado com as abstrações ideais, lembrando que são sempre abstrações, portanto, não absolutizando-as, o que retiraria a possibilidade da crítica - essa ferramenta que as sociedades democráticas inventavam para se autocorrigir - afinal sociedades perfeitas não reservam lugar para a crítica, atitude que seria tachada de insana, pois como alguém pode ser contra a perfeição?

Mas precisamos, como quer Morin (1990) conviver com as incertezas, não fazendo delas motivo para o imobilismo, a final, como pensa Nietzsche, "não é por ser coxo que não se vá andar". Não é possível esperar o fim da vida para se ter uma posição a respeito da vida, ou só abrir a boca quando tivermos absoluta certeza.

A vida, como alguém já disse, não é um mero exercício de geometria. Segundo Savater (2000), ela se assemelha mais a contos do que contas, por isso podemos afirmar que a educação para a vida, ou na "escola da vida", é feita por amadores e generalistas que não esperaram o advento da escola e seus especialistas para aprender e ensinar a viver. Precisamos então reconhecer o caráter de "artifício" da escola, ou de qualquer outra instituição educati-

feixe de feno e, colocando-a a frente do animal, este se põe a caminhar no intuito de alcançá-la. O burro, por sua vez, não percebe que, utilizando uma expressão nietzscheana, seu horizonte (aqui seu alimento) se desloca com ele. va, para melhor situar sua especificidade.

\section{Voltando aos Acontecimentos}

Esse turbilhão de ideias ficou nos incomodando por dias, semanas, e este tema começou a fazer parte das nossas vivências, em tudo o que olhávamos e pensávamos, conseguíamos ver a ideia de condição humana e foi então, que surgiu um casamento entre o Projeto do Mosaico, o qual já conhecíamos e estávamos envolvidas em outros momentos, e o debate iniciado em nossas aulas.

Começaram então, os preparativos para o "casamento", e as primeiras mobilizações foram iniciadas, o contato com direção da escola, a troca de ideias com o "professor provocador", e o chamamento da comunidade escolar. Isso tudo era de tamanha importância, que gostaríamos que mais pessoas pudessem compreender e contribuir (de acordo com seu entendimento) com o projeto, para que juntos pudéssemos enriquecer as ideias.

Assim, as primeiras formas de intervenção se deram através dediálogos, com pais, alunos, professores e comunidade externa estendendo o convite para que estes pudessem integrar o grupo e dar suas contribuições, da maneira que se enxergassem e se desafiassem a participar do projeto.

Assim sendo, o grupo foi se constituindo, com diferentes pessoas, de diferentes idades e realidades, e fomos aos poucos nos dando conta, da responsabilidade que tínhamos em fazer esta ideia se concretizar para além do pensar sobre ela. Foi então que começou o nosso desafio de como iriamos fazer este grupo refletir sobre a condição humana, e ainda mais, como fazer refletir através das diferentes 
linguagens expressivas que compunham a escola, como a dança, música, lutas, artes.

Tendo a dimensão de que estávamos trabaIhando com diversas pessoas, de várias faixas etárias, fomos organizando os mini grupos que se encontravam semanalmente para ir produzindo forma e sentido ao grande tema, que por fim terá o objetivo de se unir num grande MOSAICO.

\section{As ideias vão ganhando vida}

Depois dos convites em forma de provocações, a comunidade escolar sentiu-se "desestabilizada", e vieram à procura do grupo para participar. Este, que aqui chamaremos de grupo norteador, foi se constituindo, por professores, alunos, pais, todos de diversas faixas etárias, o grupo fazia encontros semanalmente para organização e troca de ideias.

Desta maneira, era nossa a responsabilidade de articular, o debate teórico sobre a condição humana e sua materialização no grande grupo, para isto precisávamos usar nosso conhecimento em expressividade, dança e movimento, com os quais já tínhamos algumas experiências pessoais do curso de educação física e de outras vivências. Sendo assim nestes encontros semanais com o grupo norteador, fomos desconstruindo e tornando palpáveis fragmentos do texto Condição Humana e Educação, de forma que o movimento pudesse contemplar as ideias desta temática.

Então, aos poucos fomos propondo ao grupo, situações que se reportavam as questões da condição humana através do movimento e expressão, por meio de dinâmicas, com diferentes materiais, e o contato com o outro, que foram conduzindo este a novos significados e sentidos atribuídos pelo grupo, os quais enriqueciam e iam dando forma ao percurso que estávamos buscando 6 .

A cada encontro trabalhávamos com um fragmento do texto, para podermos dar vida a aquelas ideias. Um destes fragmentos era sobre como estamos inseridos no mundo, e como tudo que esta a nossa volta nos compõe, o autor cita esta ideia como uma "teia de significados" através da qual nós humanos nos inserimos no mundo, fazendo nossas relações e ajudando a "tecer/compor" esta teia. Para materializar esta ideia, buscamos alternativas em materiais diversos, como elásticos, barbantes, tecidos, criando uma "teia gigante" e mostrando como podemos através do movimento corporal, "tecê-la", movimentá-la e usar a imaginação. E desta forma fomos aos poucos "tecendo" o nosso mosaico, e dando direcionamento ao que cada subgrupopoderia fazer, ou seja, nós debatíamos, relacionávamos, e juntamente com o coordenador de cada subgrupo, lançávamos as ideias para que este levasse aos seus, e no seu contexto, se apropriando da sua linguagem pudessem transformar o diálogo em arte, e demonstrar ao final do Mosaico.

Todo este processo causou indagações e curiosidades, pois trabalhávamoscom grupos muito diferentes, de faixa etária de uma média de 6 a 60 anos, desta forma seus entendimentos sobre a temática, eram por vezes polos muito distantes, o que exigiu que em muitos momentos as ideias fossem repensadas e reformuladas para que tudo aquilo realmente fizesse sentido, desde a criança pequena, que esta se inserindo, se encontrando na teia complexa que é a vida, ao adulto que já faz parte,

6 Esforço que podemos designar de "tradutibilidade" (Benja$\min , 2007$ ) 
mas que passou a se perceber nela.

\section{Abrindo as cortinas: Mosaico em cena!}

Quero começar mas não sei por onde! Onde será que o começo se esconde? ${ }^{7}$ A primeira cena, foi desenvolvida com a linguagem dos sons corporais e da música, compondo um jogo de vozes e expressões, que foi explorado pelo grupo de professores da escola, envolvendo os professores da Educação Infantil até o Ensino médio, docentes das áreas de história, inglês, física, língua portuguesa, filosofia, matemática, educação física, entre outros. Esta cena se encarregou de uma espécie de sumário, que por meio de perguntas, foi desenhando o percurso do espetáculo.

Figura 1: Quero começar, mas não sei por onde.

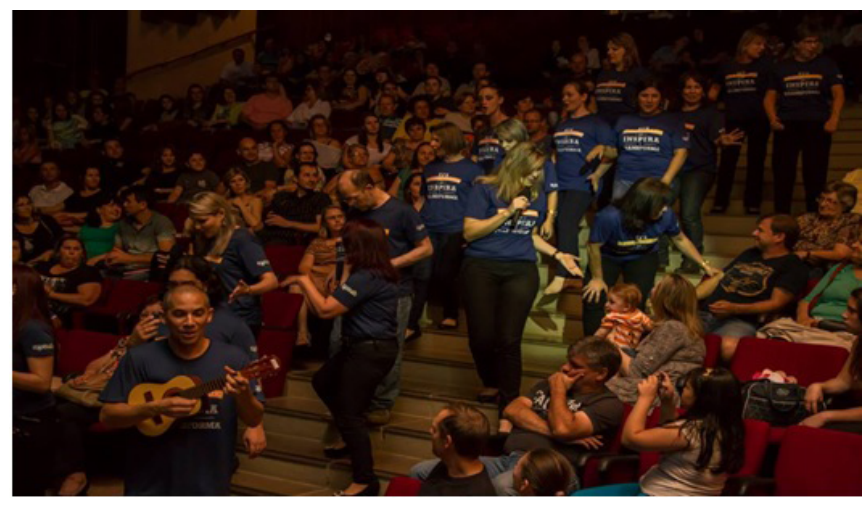

Fonte: arquivo da escola. Outubro, 2014.

Para dar sequência, utilizamos de um recurso tecnológico que por meio de imagens e sons, mostrou diferentes formas de como viemos ao mundo, diferentes formas de nascimento, sejam de animais, ou humanos, insetos etc. O vídeo foi produzido pelo responsável do Marketing da escola, mostrando como nasce-

7 Fragmento da música do grupo Tiquequê. mos de formas diferentes. E tentando questionar: Nascemos todos iguais, mas o que nos diferencia?

Dessa maneira, nascemos e vamos aos poucos nos tornando humanos, e uma das formas com que isso acontece foi representado pelo grupo de Ballet da academiavizinha da escola, demostrando o inicio das aprendizagens, as descobertas com o outro, a descoberta de sim mesmo.

Para tanto, surge em meio a estas cenas, um personagem estranho, chamado carinhosamente de "Louco", ele vem com características peculiares, olhar atento, caminhar leve, chamando a atenção do público e gerando a estranheza pelo diferente; ele faz sua passada pelo palco e pela plateia e sem dizer nada desestabiliza o olhar e atenção de todos. ${ }^{8}$

Figura 2: o louco.

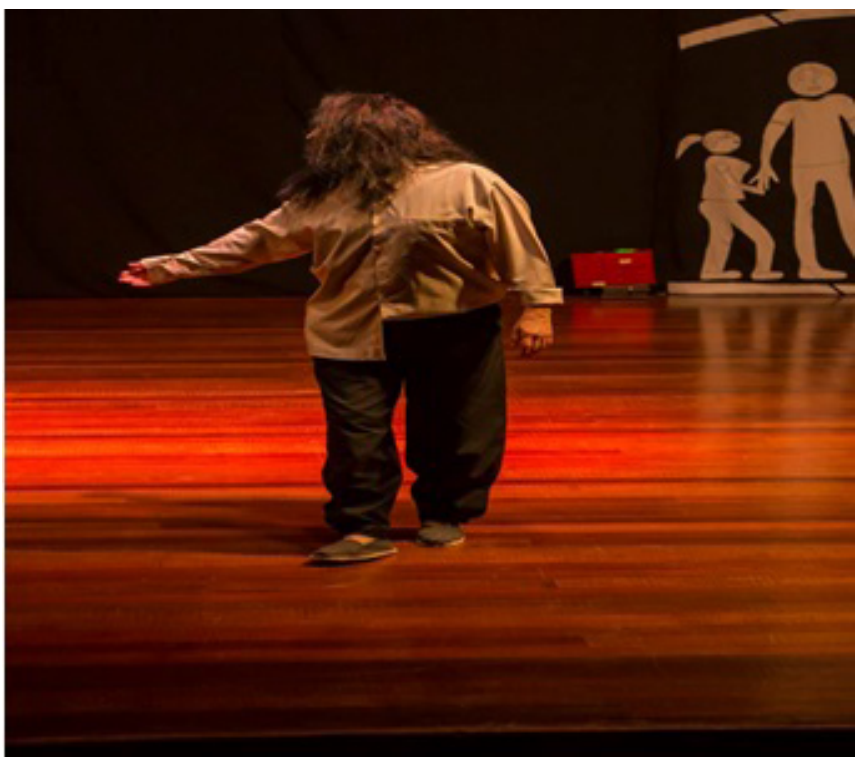

Fonte: arquivo da escola, 2014.

Assim a quarta cena vai se compondo, e nela, a ideia é justamente compor. A tentativa foi no universo da linguagem musical, em

8 O louco aparece aqui como a dimensão demens do humano, que não coube na construção racional do mundo, exterioridade que permite a ele o estranhamento, do qual, os "normais", estão esquecidos. 
que o maestro tenta unir as notas, e formar uma melodia, nos remetendo a ideia de que aos poucos vamos nos compondo, vamos crescendo, vamos articulando os diferentes e quando percebemos, temos "algo" formado, pensamentos formados, ideias.

Figura 3: a banda.

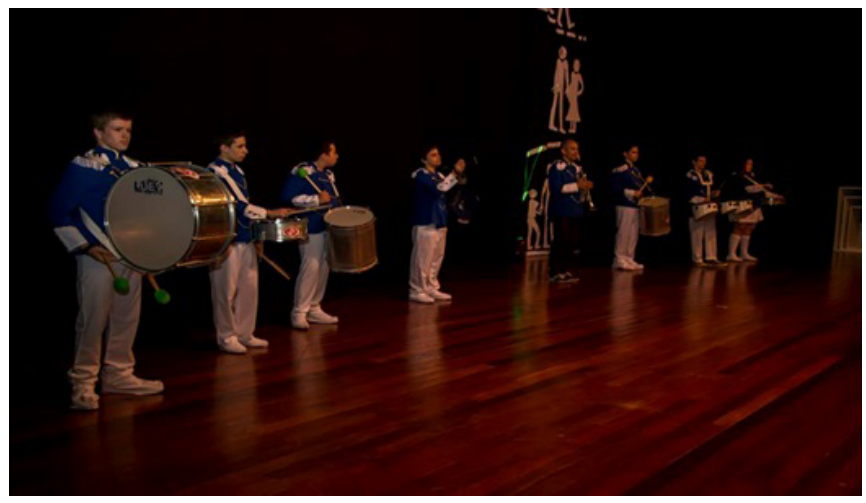

Fonte: arquivo da escola, Outubro, 2014.

Por meio disso, vamos sendo inseridos no que chamamos de "teias", e o grupo norteador demostra essas ideias com elásticos que horas se inserem um no outro, mas que também trocam lugares, e formam novas teias, novos significados, novas propostas. E nesse turbiIhão de significados o personagem do "LOUCO" reaparece em palco, com uma passada firme, marcada por sons pesados, ele transita e mais uma vez o clima de estranhamento paira ao ar.

Figura 4: teia de elástico.

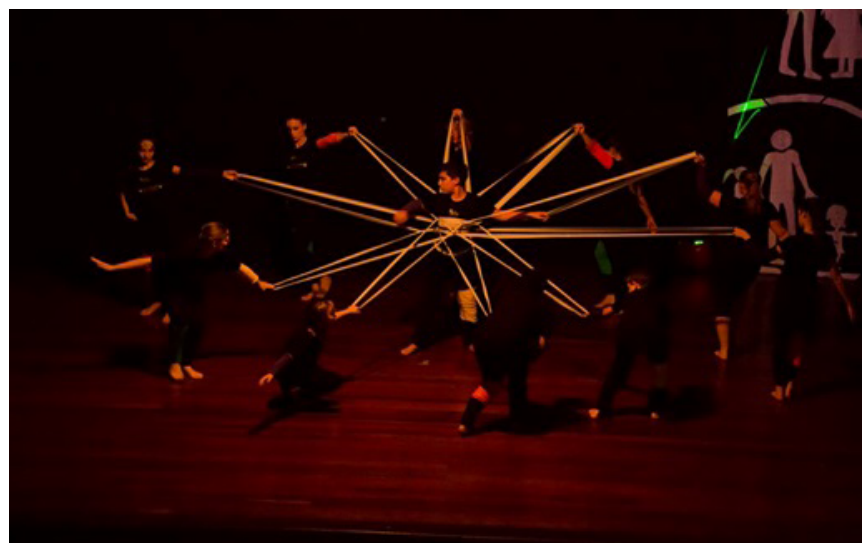

Fonte: arquivo da escola. Outubro, 2014.
Mas o significado das "Teias" são justamente de poder aprender com o outro, mas também ir se constituindo e fazendo diferença. Esta mensagem foi passada pelo grupo de crianças do projeto de dança, em que por meio dos movimentos demostraram o quanto é possível aprender com o outro, mas também colocar sua cara e mostrar novos caminho/ movimentos.

Assim, como o ser humano se constitui por diferentes modelos civilizatórios e culturais, o grupo convidado da academia, explora a modalidade do jazz, e representa a ideia de já estar mergulhados em uma cultura, e já estar sendo pouco a pouco "moldados" por esta cultura e hábitos.

Nesse mesmo viés, o grupo norteador configura a cena seguinte com caixas quadradas, de vários tamanhos, remetendo-se a analogia das "melancias quadradas" cultivadas pelos japoneses (que é citado no texto), afirmando que os seres humanos desenvolvem-se no interior de caixas de vidros. Porém, diferentes das melancias, nós seres humanos, não temos um modelo natural, pois ser "humano", já é estar mergulhado na cultura. Assim, o grupo dialogou com as caixas, construindo relações, ora dentro, ora fora, em cima, embaixo, entre as caixas, como a dizer, o problema não são as caixas, afinal, sem elas não há humanos, mas a sua retificação, que produz a coisificação do humano.

Figura 5: aprender com o outro.

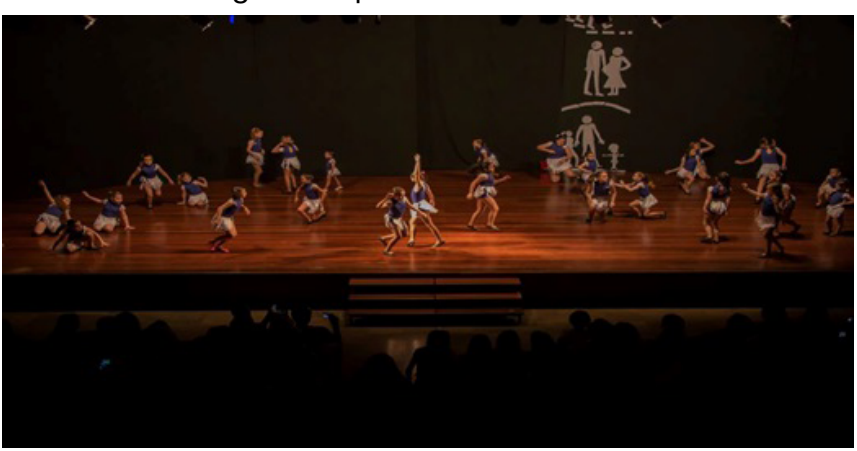

Fonte: arquivo da escola. Outubro, 2014. 
Figura 6: jazz.

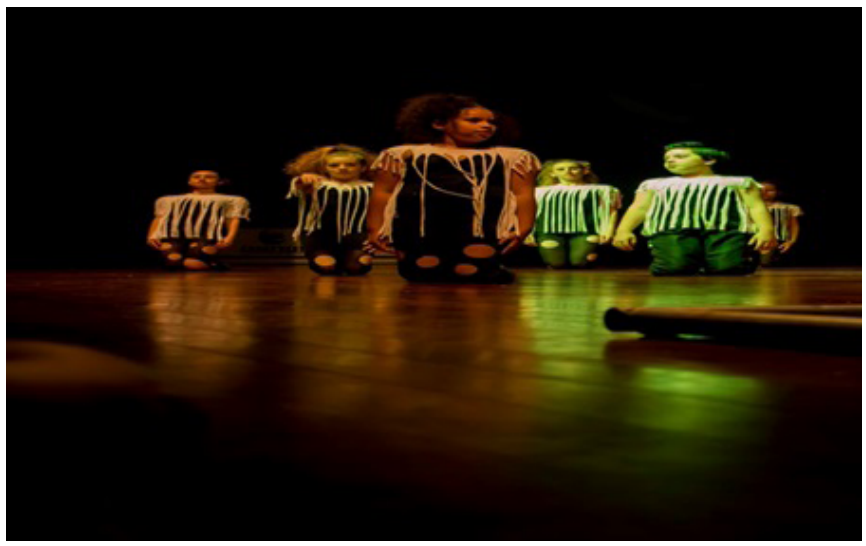

Fonte: arquivo da escola. Outubro, 2014.

Figura 7: caixas.

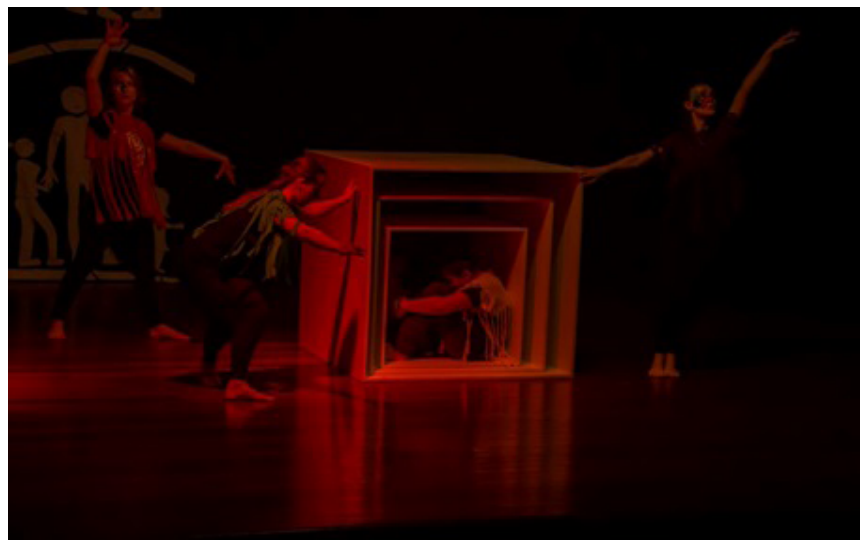

Fonte: arquivo da escola. Outubro, 2014.

Figura 8: caixas de vidro.

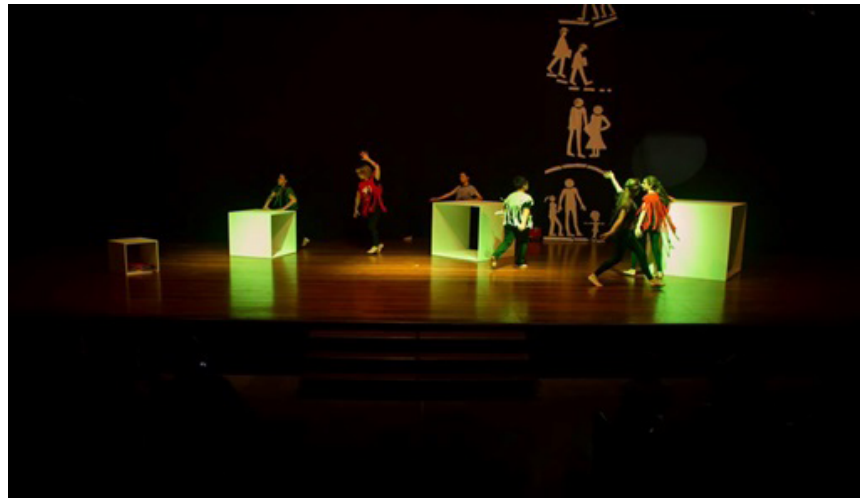

Fonte: arquivo da escola. Outubro, 2014.

A capoeira, como linguagem corporal, une movimentos do jogo de capoeira, ligando diferentes partes do corpo, formando uma grande teia, e reafirmando que muito de nós, também tem influência do outro, que nossos atos estão relacionados com o outro e com o mundo, numa constante troca, de forma dialógica.
Figura 9: capoeira.

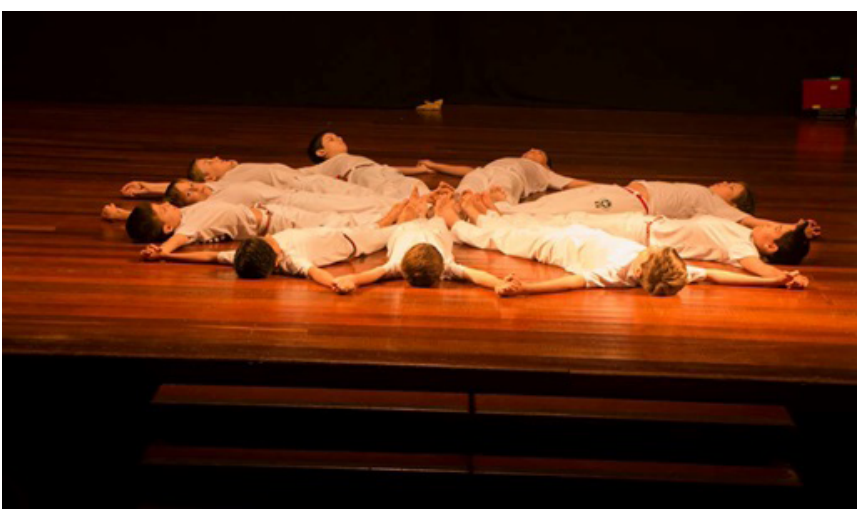

Fonte: arquivo da escola. Outubro, 2014.

Nesse constante dialogo com o mundo, a arte vem se mostrando de forma expressiva a próxima cena, uma cena aparentemente posta, na sua "normalidade", uma cena corriqueira, de certo modo comum. Foi então que dela surge a interação, e a menina (uma aluna) "sai da pintura" e da vida ao que parecia estanque, traz a arte e a expressão que nos colocam no mundo, em linguagem.

O louco aqui retorna ao palco e reforça a ideia do estranho. Do que é diferente de mim, do que sai da "mesmidade" (Skliar, 2003). Ele passa, alguns percebem, outros não. Ele intima as pessoas, ou melhor convoca por seu lugar e olhar.

A cena que batizamos como "Metades", é trabalhada com o grupo norteador, através de um pano preto, com luvas brancas nas mãos e pés dos atuantes, com metade do rosto pintado, onde ora momentos aparecem somente a "metade superior" do corpo, dando ênfase para as mãos com a luva branca, ora somente a "metade inferior" do corpo, dando ênfase para os pés com meias brancas, ora o lado direito do corpo, ora o lado esquerdo; e assim se passa uma coreografia toda atrás do pano, representando que nos humanos nunca nos damos por inteiro, e sim, sempre buscando novos significados, somos incompletos, so- 
mos metades, perspectivas, que muitas vezes não se encaixam.

Figura 10: metades.

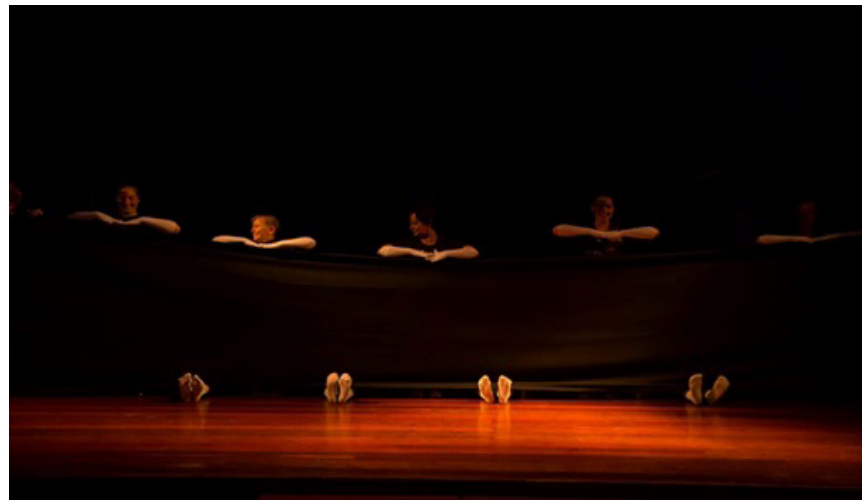

Fonte: arquivo da escola. Outubro, 2014.

Nessa mesma intenção, o projeto de Ginástica artística, recorreu a sua linguagem expressiva, como mais uma forma de enfatizar como somos constituídos, nossa incessante incompletude, nossas metades que se encaixam e também desencaixam, demostrando a eterna ideia de nunca estarmos prontos "de vez".

Neste momento entram em cena alunas de um Studio convidado, usando Kangoo (bota com "molas", utilizado em aulas de Fitness), enquanto outros, em posição de lótus, fazem meditação. Remetendo a ideia de ocidente e oriente, buscamos demonstrar que todos humanos, ao mesmo tempo em que são "iguais" podem ser diferentes, ter gostos diferentes, ideias diferentes. Completa a cena diversas pessoas passando, fazendo coisas do nosso dia-a-dia, lendo jornal, caminhando, apressados, ouvindo música, mexendo no celular, etc. No meio desta cena morre o "Louco", e ninguém vê, ninguém percebe, ninguém interrompe sua rotina, ninguém tira o foco dos seus interesses, afinal, não temos olhos para o outro,

9 Trabalhamos com a expressão "condição humana", para expressar a ideia de que o humano se dá "a cada vez", e não, "de vez", como expressa o conceito de "homem". e só nos importamos com nós mesmos ${ }^{10}$, ou o que pode nos afetar e ele era um estranho.

Figura 11: ginástica.

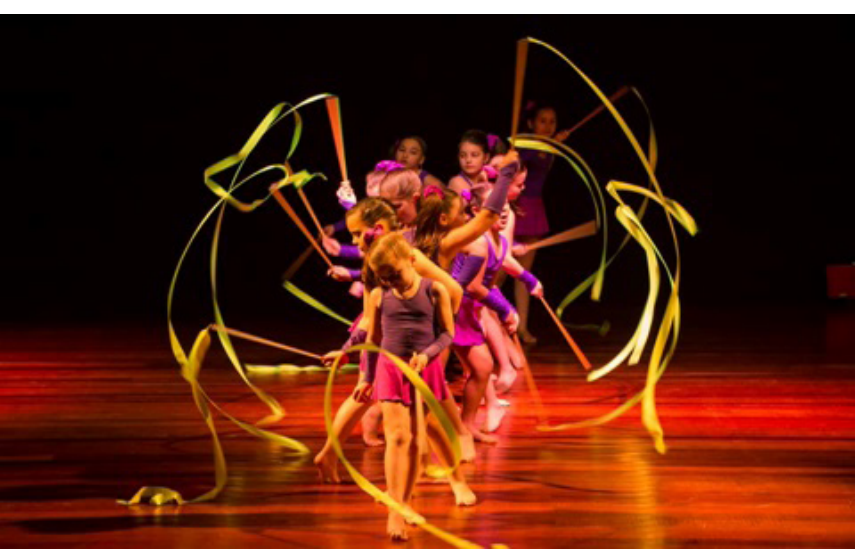

Fonte: arquivo da escola. Outubro, 2014.

Assim, a próxima cena inicia com o "velório" do Louco, que caído no meio do palco, agora vazio e escuro, vai sendo cercado por pessoas que adentram a cena portando velas. Nesta cena coloca-se ao lado do morto um personagem e recita a poesia: $A$ Morte de Pedro Ninguém ${ }^{11}$, de Luís Menezes, sendo acompanhado por um solo de violino, executado por outro personagem.

A morte quebra a normalidade da vida e reacende o conflito (representado pelas lutas que agora ocupam o palco). Ao final destas resta o campo de batalha com os corpos "mortos" pelo chão. Nesse momento entra em cena um personagem ${ }^{12}$, é Agilulfo, o qual é pura consciência, dever e vontade. "tem consciência de

10 "Narciso acha feio o que não é espelho" (Música Sampa de Caetano Veloso)

11 Disponível em: http://www.guapos.com.br/2014/poesia. php?cdpoesia=89. Acessado em jan. 2017.

12 Recorremos aqui aos personagens do livro "O cavaleiro inexistente", de Italo Calvino (1993), o qual expressa o dilema da condição humana e sua corporeidade. Apresenta ele três possibilidades de sujeitos encarnados em três personagens distintos. O três após uma sangrenta batalha tem a tarefa de enterrar os mortos "cada um escolhe um morto, agarra-o pelos pés e o arrasta até um lugar adequado para cavar-lhe a cova". 
existir mas de fato não existe", sendo só uma armadura sem corpo.

Figura 12: o poema.

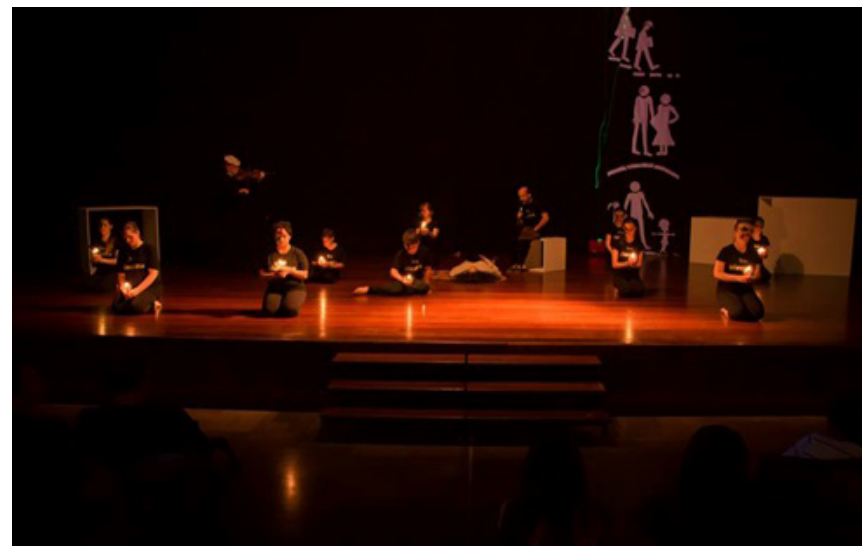

Fonte: arquivo da escola. Outubro, 2014.

Agilulfo arrasta um morto e pensa: "Ó morto, você tem aquilo que jamais tive nem terei: esta carcaça. Ou seja, você não tem: você é esta carcaça, isto é, aquilo que às vezes, nos momentos de melancolia, me surpreendo a invejar nos homens existentes. Grande coisa! Posso bem considerar-me privilegiado, eu que posso passar sem ela e fazer de tudo. Tudo - se entende - aquilo que me parece mais importante; e muitas coisas consigo fazer melhor do que aqueles que existem, sem os seus habituais defeitos de grosseria, aproximação, incoerência, fedor. É verdade que quem existe põe sempre alguma coisa de seu no que faz, um sinal particular, que não conseguirei jamais imprimir. Mas, se o segredo deles está aqui, neste saco de tripas, muito obrigado, não me faz falta. Este vale de corpos nus que se desagregam não me provoca mais arrepios que o açougue do gênero humano vivo".

O outro é Gordulu, é pura imanência com a natureza, confunde-se com ela, é pura sensibilidade corpórea ("existe mas não tem consciência disso"). Gordulu arrasta um morto e pensa: "Você dá certos peidos mais fedidos que os meus, cadáver. Não sei por que todos se compadecem de você. O que lhe falta? Antes, se movia, agora seu movimento passa para os vermes que você nutre. Fazia crescer unhas e cabelos: agora vai produzir líquidos que farão crescer mais altas sob o sol as ervas dos campos. Vai se tornar capim, depois leite das vacas que comerão capim, sangue de criança que bebeu o leite, e assim por diante. Ó cadáver, você é mais capaz do que eu para viver?".

Figura 13: Agilulfo.

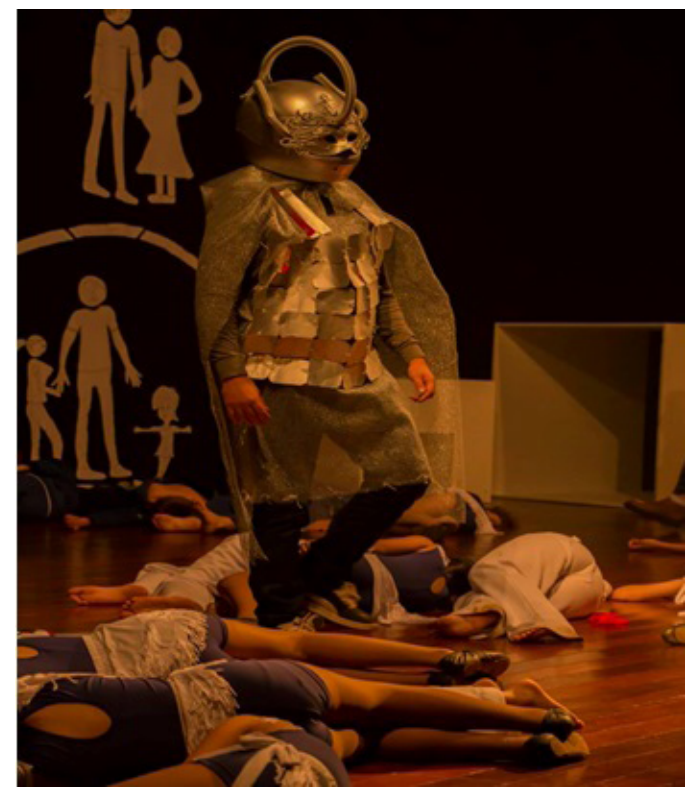

Fonte: arquivo da escola. Outubro, 2014.

Figura 14: Gordulu.

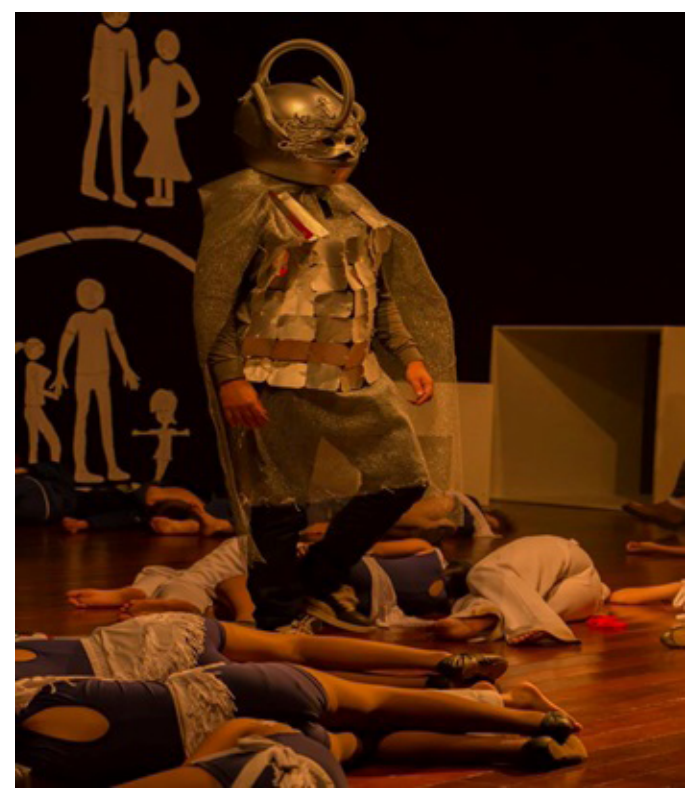

Fonte: arquivo da escola. Outubro, 2014. 
O terceiro é Rambaldo, traduz a ambiguidade da condição humana, pois é uma espécie de consciência encarnada, ou um corpo com consciência. Buscava ele um frágil ponto de equilíbrio entre os dois primeiros.

Rambaldo arrasta um morto e pensa: "Ó morto, corro, corro para chegar até aqui como você, a me fazer puxar pelos calcanhares. $O$ que é esta fúria que me empurra, esta mania de batalhas e amores, vista do ponto onde observamos seus olhos arregalados, sua cabeça virada que bate nas pedras? Penso, ó morto, você me obriga a pensar; mas o que muda? Nada. Não existem outros dias senão estes nossos dias antes do túmulo, para nós, vivos, e também para vocês, mortos. Que me seja concedido não desperdiçá-los, não perder nada daquilo que sou e daquilo que poderia ser. Praticar ações insignes para o exército. Abraçar, abraçado, minha orgulhosa amante. Espero que você não tenha gasto seus dias de modo pior, ó morto. De qualquer maneira, para você os dados já decidiram seus números. Para mim ainda se agitam no copo dos azares. E eu amo, ó morto, minha ansiedade, não a sua paz".

Figura 15: arrastar os corpos.

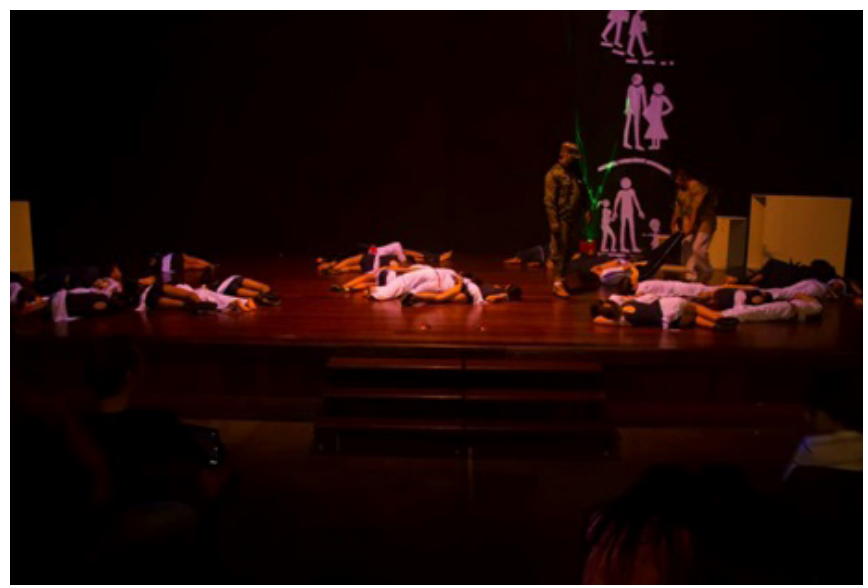

Fonte: arquivo da escola. Outubro, 2014.

Após esta cena, apagam se as luzes e crianças vestidas de branco deitam-se ao lado dos "mortos" e, no acender das luzes, levantam e levantam os "mortos" dando-Ihes a mão, como a dizer, a morte, como a morte da semente, é a condição de novas vidas, e estas novas vidas, ressuscitam os mortos ao dar vida a tradição. Em meio a esta cena, entra um personagem, caminhando lentamente e recitando o verso de Homero: "Como as folhas das florestas são as gerações dos homens. Veja, a uns o vento disperso e a outros o madeiro vicejante faz brotar no tempo da primavera. Assim são as gerações dos homens, esta cresce, aquela desaparece" (apud Rabuske, 2008, p. 10).

Fecham-se as cortinas, restando a sensação de que "a coisa mesma", diria Mário Quintana, tem a sensação de que não foi dita, algo que o pensamento kantiano já nos alertava, por isso, nos sobra as "acontecências", o que, convenhamos, não é pouco.

Referências

ARENDT, Hannah. Entre o passado e o futuro. São Paulo: Perspectiva, 2002.

BENJAMIN, W. Conceptos de filosofia de la historia. La Plata: Terramar, 2007.

CALVINO, I. O cavaleiro inexistente. São Paulo: Companhia das Letras, 1993.

FENSTERSEIFER, P.E. Condição humana e educação. Texto Didático. s/d.

GEERTZ, C. A interpretação das culturas. Rio de Janeiro: Guanabara Koogan, 1989.

KANT, I. Sobre a pedagogia. Trad. Francisco Cock Fontanella. Piracicaba: Editora Unimep, 1996.

MERLEAU-PONTY, M. Fenomenologia da percepção. São Paulo: Martins Fontes, 1994. 
MENEZES. L. A morte de Pedro ninguém. Disponível em: http://www.guapos.com.br/2014/ poesia.php?cdpoesia=89. Acessado em jan. 2017.

MORIN, E. Ciência com consciência. Portugal: Publicações Europa América, 1990.

RABUSKE, E. A. Antropologia filosófica. 11 ed. Petrópolis. RJ: Vozes, 2008.

ROSA, J. G. Grande sertões: veredas. Rio de Janeiro: Nova Fronteira, 1986.

SKLIAR, C. Pedagogia (improvável) da diferença: e se ooutro não estivesse aí? Tradução de Giane Lessa. Rio deJaneiro: DP\&A, 2003.

SAVATER, F. O valor de educar. São Paulo: Martins Fontes, 2000.

Recebido: 14/05/2017 Aprovado: 11/09/2017 